\title{
TREATMENT OF ANIMALS
}

BEING A SPEECH DELIVERED AT THE KENSINGTON TOWN HALL ON DECEMBER 15, I9I3, AT A MEETING CALLED TO PROTEST AGAINST CRUELTIES TO PERFORMING ANIMALS

BY

JOHN GALSWORTHY

ANIMALS' FRIEND SOCIETY YORK HOUSE, PORTUGAL STREET, LONDON, W.C. 


\title{
THE "A.F." PAIMPHLET SERIES.
}

\author{
Price 2d. each, post free.
}

The best and most comprehensive Series dealing with the Treatment of Animals.

THE PITIFUL STORY OF THE PERFORMING ANIMAL. By AN EX-Trainer. Edited by C. R. Johns, with Preface by ERNist ErLt.

TREATMENT OF ANIMALS. By John GaLsworthy. Just published.

A speech delivered at a Meeting "to protest against cruelties to performing animals.

FOR LOVE OF BEASTS. By John GaLsworthy.

Four Dialogues about Animals. Reprinted from the Pall Mall Gazette.

WAYS OF HELPING. By LetTice MACNAGHTEN. Illustrated. [Price id.]

Makes suggestions of ways in which all may give some help towards lessening cruelty to animals.

HORSES IN WARFARE. By ERNEST BeLL, M.A., and H. BaILlie-WeAver, LL.B.

A plea for the inclusion of horses in the merciful provisions of the Geneva Convention.

A PLEA FOR HORSES IN WAR. By the Hon, Mrs. Charlton.

HORSE-RACING, A CRUEL SPORT. By ERNEST Bell, M.A.

A serious indictment of our National Sport.

DOCKING AND NICKING. BY J. LEE OSBORN.

Shows the foolishness and cruelty of these fashionable mutilations as practised upon horses.

DOG-STEALING. By C. R. Johns.

A full account dealing with the Reasons, Methods, Treatment, Dog Shops, the Legal Position, etc.

SPORT. By G. G. GREENWOOd, M.P.

$\mathrm{Mr}$. Greenwoot reviews in turn the chief blood-sports: Fox-Hunring, WiLd and Tamr Derr-Hunting, Pheasant-Shooting, Rabbit-Codrsing, etc., and pronounces against them all on the grounds of humanity and reason.

THE HUNTED OTTER. By Joseph Collinson.

A comprehensive account of the otter and his ways, and a trenchant condemnation of the otter worry.

HOW SEALSKINS ARE OBTAINED. By JOSRPH Collinson.

An account, based on the evidence of eyewitnesses, of some of the methods by which the seals are hunted.

CRUELTIES IN DRESS. BY JESSEY WADr.

A consideration of the cruelties involved in procuring furs, feathers, and gloves.

MOTHER LOVE IN THE ANIMAL WORLD. BY JESSEY WADE.

BIRD-CAGING AND BIRD-CATCHING. By ERNEST BELL, M.A.

An attempt to show that the caging of birds necessarily involves much cruelty and is unjustifiable.

HUNANE SLAUGHTERING. How to work Petitions to Local Authorities, with Preface by R. C. P. PAdDison. 


\section{TREATMENT OF ANIMALS}

BEING A SPEECH DELIVERED AT THE KENSINGTON TOWN HALL ON

DECEMBER 15, 1913, AT A MEETING CALLED TO PROTEST AGAINST CRUELTIES TO PERFORMING ANIMALS

JOHN GALSWORTHY

ANIMALS' FRIEND SOCIETY YORK HOUSE, PORTUGAL STREET, LONDON, W.C. 

Mr. Chairman, Ladies and Gentlemen, -

I am here to say a few, very few, words-not on the particular object for which this meeting has been called-but on the whole question of the treatment of animals by our civilised selves. For I have no special knowledge, like some who will speak to you to-night, of the training of performing animals, I have only a certain knowledge of human and animal natures, and a common sense which tells me that wild animals are more happy in freedom than in captivity; domestic animals more happy as companions than as clowns. And-quite apart from definite question of inhumanity - of which I personally have no right to speak-it is perfectly clear to me that these animal shows are among the many surviving evidences, the lingering symptoms, of a creed that-thank heaven!-is beginning to pass, and must pass, from us. That creed said: We human beings have the right, for our pleasure, convenience, and distraction, to disregard in the matter of dumb creatures, those principles which our religion, morality, and education have fixed as the guiding stars of our conduct towards human beings. (In parentheses-please note, that I do not to-night touch on the question of our rights over dumb creatures in so far as our actual selfpreservation is concerned; I limit my words for the moment to pleasure, convenience, and distraction.)

Now: "Do unto others as you would they should do unto you!" is not only the first principle of Christianity, but the first principle of all social conduct; the essence 
of that true gentility which is the only saving grace of men and women in all ranks of life. And I am as certain as that I stand here, that the word "others" cannot any longer be limited to the human creature. Whether or no animals have what are called "rights" is an academic question of no value whatever in the con. sideration of this matter. But, lest there be anyone who wishes to take up this point of abstruse philosophy, I will admit at once that animals have no more rights than have babies under the age when they may be said to have duties (on which rights, as we are told, depend), that animals have no more rights than imbeciles, or those who are deaf, dumb, and blind. Rights or no rights, I care not; the fact remains that by so much as we inflict on sentient creatures unnecessary suffering, by so much have we outraged our own consciences, by so much have we fallen short of that secret standard of gentleness and generosity that, believe me, is the one firm guard of our social existence, the one bulwark we have against relapse into savagery. Once admit that we have the right to inflict unnecessary suffering, even on a fly, and you have destroyed the very basis of human society, as we know it in this age. You have committed blasphemy-the only blasphemy that really matters-blasphemy against your conscience. For the true conscience of this country has ranged itself definitely against the infliction of umecessary suffering on any sentient thing. And the concrete proof of this lies in the wording of the law against cruelty to animals, with its definition of "cruelty" as the infliction of unnecessary suffering; for, mark you, in a country like this, the law does not precede, but follows, the true conscience of the age. 
I should like just to quote to you shortly the law, and the latest judicial dictum upon it.

Section I. (I) of the Protection of Animals Act, IgIr.

"If any person (a) shall cruelly illtreat any animal ... or being the owner shall by ... unreason. ably doing or omitting to do any act ... . cause any unnecessary suffering," he shall be guilty of an offence.

Mr. Justice Darling, on November Igth last, in the Court of Appeal, said:-

"Where unnecessary suffering is caused by some act of an owner, it cannot be justified on the ground of old custom, and of benefit to commercial persons."

Ladies and gentlemen, nothing so endangers the fineness of the human heart as the possession of power over others; nothing so corrodes it as the callous or cruel exercise of power; and the more helpless the creature over whom power is cruelly or callously exercised, the more the human heart is corroded. It is the recognition of this truth which has brought the conscience of our age, and with it the law, to say that we cannot any longer with impunity regard ourselves as licensed torturers of the rest of creation; that we cannot, for our own sakes, afford to admit the infliction of unnecessary suffering on any living thing.

In all this matter then, of the treatment of dumb animals, it comes to the definition of the words 'unnecessary suffering.' And I say this: All suffering that is inflicted merely for our pleasure, distraction, and even for our convenience, as distinct from our preservation, is unnecessary and an abomination. And the fact that it 
is inflicted on creatures unable to raise hand to help themselves, or voice to tell us what they suffer, makes it ever the more black and abominable. Whether it be the destruction of mother-birds (with their whole families of nestlings) for the sake of their nuptial plumes, to be worn in the hats and hair of human mothers; or the painful docking of the tails of horses, their sole weapon against the torment of stinging flies, for the sake of a hideous fashion; whether it be the treacherous sale of horses worn-out in our service; the snaring of rabbits in needlessly cruel traps; the turning adrift of friendly but unwanted dogs and cats; whether it be the unnecessarily slow and painful slaughtering of animals for food; the godless keeping in captivity of wild songbirds; the prisoning of eagles, hawks, and many another creature that cannot bear confinement, in zoos and other places; whether it be any of these, or this sometimes distressing and always unnatural training of performing animals-in all, suffering is inflicted for our pleasure, distraction, or convenience, and all of it is unnecessary, all of it is against the conscience of the age.

To those who are tempted by the devil of irreflection to say: "But this is the creed of sentiment and softness," I feel bound to answer: "I fear no man ever became a stoic, no man ever acquired the virtues of fortitude and courage, by inflicting pain on others." There is nothing in this new creed that prevents anyone from inflicting on himself as much hardship, risk, and privation as he considers needful to make him hard and brave.

Let me draw your attention to a strange anomaly, which accounts for most of our callousness towards the sufferings of animals. Nearly everyone who witnesses 
with his own eyes the infliction of unnecessary suffering on an animal, feels revolted, and even hastens to the creature's aid; yet the vast majority of these same men and women, merely hearing or reading of sufferings inflicted, passes by on the other side, with the feeling that to pay attention would be either credulous or sentimental. Now, in regard to credulousness, it is worth noting that it is hardly ever to the interest of anyone to draw attention to cruelty, certainly not to fabricate such a charge; very much the contrary. And in regard to sentiment, there seems to be a slight confusion as to the meaning of that word. A man only moved by cruelty seen with his own eyes is no wit less sentimental than the man who takes fire at the mere recital of it; he is only lazier in mind, more deficient in understanding, more sluggish in blood. Just as sentimental, but less sympathetic. The longer I live, the more I become convinced that people only use that favourite reproach - sentimentaltostigmatize sympathy with sufferings that they themselves have been unwilling or unable to realise. The moment they do realize, they become just as "sentimental," just as moved by pity and anger-for that is what the word sentimental truly means-as those at whom they sneer.

Let that be put into the pipe and smoked! For this sluggishness of our imaginations is the very heart of the matter.

Oh! says the public, but even if there be suffering to the animals, the pleasure that their freaks or their fur or their feathers give us is greater than this suffering; we are entitled to weigh the one against the other. Yet, not one-tenth of that same public would dream of saying this if, with their own cyes, they had seen that 
suffering, for then the pleasure they talk of would have vanished in the memory of those quivering visions of the unhappiness or torture of dumb creatures. Out of sheer sluggishness of imagination, out of mere laziness of mind, then, is made that truly pitiable plea-our pleasure is greater than their suffering.

Yes! Nearly all the suffering we inflict, whether on human beings or on animals, comes from our not thinking. I know, of course, that many people gravely distrust that practice. For all that, I venture to suggest that a little more thought will do no harm to any of us.

Friends, we pass this way but once, but once tread this world, but once live in communion with these furred and feathered things, many of them so beautiful, in a thousand ways so like ourselves, often so friendly if we would let them be, and yet who, one and all, are so simple and so helpless in the face of our force and ingenuity. Shall we, as, each one of us, we pass out, say: "I have lived my life as a true lord of creation, taking toll from the captivities and sufferings of every creature that had not my strength and cunning!" Or shall we pass out with the thought: "God forgive me, if I have given more pain than I could help to any sentient thing!"

JOHN GALSWORTHY. 


\section{THE SENTIMENTAL VEGETARIAN. By M. LitrLe.}

While admitting the claims of the hygienist and moralist, Miss Little shows that the Sentimental Vegetarian has the strongest position of all.

ANIMALS UNDER BRITISH RULE. By the Hon. Mrs. CharLION,

With seven half-tone Illustrations.

This is a concise illustrated description of certain cruelties practised in India, including flaying goats alive, branding with hot irons, manufacturing monstrosities, the torment of thirst.

ANIMALS IN THEIR RELATION TO EMPIRE, By the Hon. Mrs.

Charlion. Reprinted from the Nineteenth Century.

A serious indictment against the British, who are largely responsible for the treatment of animals in India.

CRUELTY TO ANIMALS IN INDIA. By the Hon. Mrs. Charlion.

Being extracts from "Heirlooms of Empire." Reprinted from the Nineteenth Century.

HUMANE TEACHING IN SCHOOLS. By PROF. J. HOWARD MOORE.

A plea for humane instruction in schools as the most important item in education.

THE TEACHING OF INHUMANITY. By EMILy Cox, M.A.

The object of this pamphlet is to show that much of the cruelty or callousness which we are apt to regard as "innate" in human nature is not really innate at all, but is the direct result of our inhuman teaching of children.

WHY DO ANIMALS EXIST? By ERNEST/BELL, M.A. Written to combat the very prevalent idea that animals were creafed for man's use and pleasure.

THE RIGHTS OF ANIMALS, By ERNEst Bell, M.A. An inquiry in to the theoretical rights of animals and their practical application in daily life.

AN AFTER-LIFE FOR ANIMALS, By ERNEST BELL, M.A.

An argument that the reasons which point to an after-life for humans apply also to the sub-humin races.

Price Is. 3d. per Set of 16 Cards, post free.

\section{The "Animals' Friend" Kindness Cards.}

A Series of 16 Coloured Picture Cards, $6 \times 4^{\frac{1}{2}}$ inches, with simple and instructive letterpress on the back.

The object of these cards is to enlist the sympathy of children and uneducated people, to whom pictorial representation appeals most readily, and to give them, in simple language, some reasons for taking an intelligent and kindly interest in the animals who live with us. It is hoped that they will be found useful both for instruction in schools and also in Bands of Mercy. 


\section{“ANIMALS' FRIEND" LEAFLETS}

Price $\frac{1}{2} d$ each, or 50 for $1 /-$, post free.

THE HORSE'S PRAYER, also as a Poster. Price rado THE COLLIER'S DOG. BY MOSES LEE.

DRIVING. By A. F. and C. Carter.

IS HORSE RACING CRUEL? By ERTEST BELL.

GUINEA-PIGS AND WIVES. By G. G. Greenwood, M.P.

THE Chaining of Dogs. By ErNest BrLl.

A LETHAI. BOX FOR CATS. By Horace SNow.

SEALSKINS. By Joseph Collinson.

FUR COATS. BY JESSEY WADE.

THE COST OF A SKIN. By Prof. J. Howard Moore.

HATS AND THE WOMAN. By Jessey Wade.

EGRET PLUMES. BY W. DUTChER.

OSTRICH FEATHEIS: A Dialogue. By ERnKST BrLL.

IS IT CRUEL TO KEEP BIRDS IN CAGES? BY ERNEST BELL. CHRISTMAS CHEER: What it Means. By ERnest BrLt.

LITTLE FATHER CHRISTMAS. By JESSEY WADE.

HUMANITY AND DIET. BY ERNEST BELL.

WHAT ARE THE RIOHTS OP ANIMALS? BY ERNEST BELL.

"PASS ON" LEAFLETS (Supplied Free).

HORSES IN WAR. BY ERNEST BELL.

THE CHURCH ATD CRUEL SPORTS. BY JOSEPH CoLLINBON. TORTOISESHELl: How it is Procured. By Ernest Brll.

TINY DOGS : How they are Manufactured. By Mrs. Kenningale Coox.

THE OTTER WORRY. By Norman Gale.

THE PITILESS HUNT OF THE OTTER. By JOSEPH COLLINSON. HUNTED FOR SEVEN HOURS.

MR. ANDREW LANG ON OTTER HUNTING.

THE CRUEL STEEL TRAP. BY JEROME K. JEROME.

WINTER CRUELTIES. BY JESSEY WADE.

JUVENILE CRUELTY. BY ERNEST BELL.

ANINALS' FRIEND SOCIETY. 